\title{
PAVLIV SESSION CONTINUES: ANNIVERSARY OF SEVEN DECADES FOR PSYCHOLOGY
}

\author{
Sergii Boltivets \\ State Institute of Family and Youth Policy of Ukraine, Ukraine \\ E-mail: boltivetssergij@i.ua
}

Seven decades have passed since the "Scientific Session on the Problems of the Physiological Teachings of Academician IP Pavlov" from June 28 to July 4, 1950. Its main direction was the assertion of the leading role of the cerebral cortex with the subordination of all physiological processes reflected in the conditioned reflexes defined by IP Pavlov. JV Stalin's interference in the session is reflected in his comment: "In my opinion, the greatest damage to Pavlov's teachings was caused by Academician Orbeli... The sooner Orbeli is exposed and the more thoroughly his monopoly is eliminated, the better. Beritov and Stern are not so dangerous, because they oppose Pavlov openly and thus facilitate the reprisal of science over these artisan artisans... Now something about the tactics of combating opponents of the theory of Academician Pavlov. We must first secretly gather supporters of Academician Pavlov, organize them, distribute the roles, and only then gather a meeting of physiologists... where it will be necessary to give opponents a general battle. Without this, you can fail. Remember: the enemy must be beaten with the expectation of complete success "[Stalin, 2005].

Revealing certain periods of repression, researchers are unanimous in their constant use by the leadership of the former Soviet Union, which intensified based solely on the repressive possibilities of their implementation but did not stop during the entire period of so-called Soviet, but in the spirit and speech of Russian authorities' territory.

Only in recent decades has the publication of materials that previously had the status of secrecy begun. It is becoming increasingly clear from them that Ivan Pavlov condemned the October coup, later renamed the "revolution": "We drove this idea into the dictatorship of the proletariat. Brain, head put down and legs up. What constitutes a culture, the mental strength of a nation, is devalued, and what constitutes a brute force that can be replaced by a machine is brought to the fore. And all this, of course, is doomed, I am a blind denial of reality. ... What is a revolution in general? It is release from all brakes... it is complete incontinence, unbridledness. There were laws, customs, etc. All this is now being nullified "[Shnol', 2020].

Mass arrests in the late 1920s and early 1930s, which also included specialists from the Institute of Experimental Medicine headed by IP Pavlov, who were released at the request of the institute's management. But this diminished the indignation of IP Pavlov, with whom he addressed the chairman of the People's Commissar VM Molotov: "Continuous and countless arrests make our lives completely exceptional. I do not know their purpose (whether it is an immensely thorough search for enemies of the regime, or a method of intimidation, or anything else), but there is no doubt 
that in most cases there is not the slightest reason for arrest, i.e., guilt in reality "[Shnol ', 2020].

With a letter against terror and violence, IP Pavlov addressed the People's Commissar for Health GN Kaminsky, who later, at the June plenum of the Central Committee of the CPSU (b) in 1937 criticized the repression of the NKVD ("So we shoot the whole party") and after his report expressed a remark to JV Stalin on the report of MI Yezhov that the NKVD continues to arrest honest people, "to which JV Stalin replied:" They are enemies, and you are a bird of the same flight. ". On the same day, June 25, 1937, GN Kaminsky was expelled from the candidates for members of the Central Committee of the CPSU (b), and on February 8, 1938 the military board of the Supreme Court of the USSR sentenced him to death and shot him on February 10, 1938.

Until the last days of his life, IP Pavlov showed his uncompromising position on the multifaceted despotism - it was a lone protest of a scientist in a totalitarian environment, the imitation of which was extremely dangerous. One can only imagine how IP Pavlov would react to the "Paul's session". However, this is the essence of the repressive policy of JV Stalin, who most valued the mission of torturers and for this role in revenge for the fact that it failed in the life of a prominent scientist, IP Pavlov was appointed by him posthumously.

JV Stalin, recognized by then ideologues in the scientific field as a "luminary of science, genius leader and teacher" thus received the authority to delegate his influence on the already dead IP Pavlov, destroying in his name the development of science, to which IP Pavlov dedicated all his own life. The dead IP Pavlov was appointed an improvised executioner of JV Stalin, a supporter of Soviet power, a dictator of science.

Thus, the "special significance of the doctrine" extended to the whole "Soviet culture and life", from which IP Pavlov became a "Soviet", whose teaching is convenient to torture not only some of Pavlov's students, but also other scientists, and perhaps in the future and figures of any cultural or vital sphere. This created a strong conviction that the "coryphaeus of science" JV Stalin had nothing to do with this torture - loyalty to the "Pauline teachings" had to be proved to other persons appointed by him.

The inferiority complex inherent in the leadership of the USSR was largely realized by him, which was expressed in a euphoric passion to replace their own fears with phantasmagoric illusions of the advantages of all Soviet as the embodiment of Russian messianism ("Moscow - the Third Rome, and the Fourth not to be"). The whole content of the Pauline session is based on this antithesis: in every report and speech it is obligatory to oppose the materialist, called by JV Stalin primary, - idealistic, advanced - reactionary, Soviet - bourgeois.

Contrasting the disproportionate is a characteristic feature of the reports of the Pauline Session, where the main goal of each speaker was to meet the expectations of the masses like them, in self-dedication to the "luminary of science" but not science, the use of criticism of predetermined objects for self-preservation, self-criticism - to dispel the suspicions of the masses of bias. All participants were part of the collective rite of initiation, the way out of which was far from obvious to them: who was shot, who was deprived of positions and titles, who was exiled, who was postponed until the next appropriate occasion.

Similarly, the main purpose of the Pauline session was to prevent independent, and from the point of view of the Soviet leadership, the unauthorized growth of scientific authority of scientists on the basis of their personal merits before science - science is an unpredictable and therefore dangerous area for those in this uncertainty at work. Such individuals are undoubtedly potentially dangerous to any totalitarian social and state system. Therefore, it was necessary to destroy the authority deserved by the scientist for his service to science, in order to replace it with the authority to serve his superiors, the leadership of his superiors - the leader. Thus, the scientist became dependent on the opinion and attitude of his superiors, rather than on the results of his search for truth. The uncertainty of the scientific sphere was thus eliminated by the controllability of the management - the opinion of the scientific superiors became the truth, the last instance of which was the highest superiors.

Over time, it may seem that the action of the Pauline session has disappeared from the current consciousness of contemporaries, and only an immersion in the history of science can return the idea of it. But this is not the case. One can agree that the younger generation may be unaware of the names, plot, and content of those events, but not the ways of organizing and influencing 
OF PSYCHOLOGY

IN THE $21^{\text {st }}$ CENTURY

Vol. 15 , No. 1, 2021

6

current and future scientific life. It can be assumed that the current scientific life has removed the obstacles and restrictions imposed by the previous totalitarian era, but most often we are faced with the fact that new generations not only revive but also complement and expand the range of obstacles and barriers to the free development of science.

\section{References}

Stalin, I. V. (2005). Pis `mo Yu. A. Zhdanovu 6 oktyabrya 1949 goda. Stalin I. V. Polnoe sobranie sochinenij. T. 18 [Letter to Yu. A. Zhdanov October 6, 1949. Stalin IV Complete Works. T. 18.]. http://sovetia.at.ua/ Stalin/Tom18.html\#t243

Shnol, S. E. (2020). Geroi, zlodei, konformisty 'otechestvennoj nauki [Heroes, villains, conformists of Russian science]. Knizhny”j dom "LIBROKOM".

Received: February 10, 2021

Accepted: June 10, 2021

Cite as: Boltivets, S. (2021). Pavliv session continues: Anniversary of seven decades for psychology. Problems of Psychology in the $21^{\text {st }}$ Century, 15(1), 4-6. https://doi.org/10.33225/ppc/21.15.04 